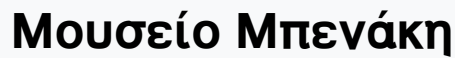

A Singular Antiquity: Archaeology and Hellenic Identity in Twentieth-Century Greece

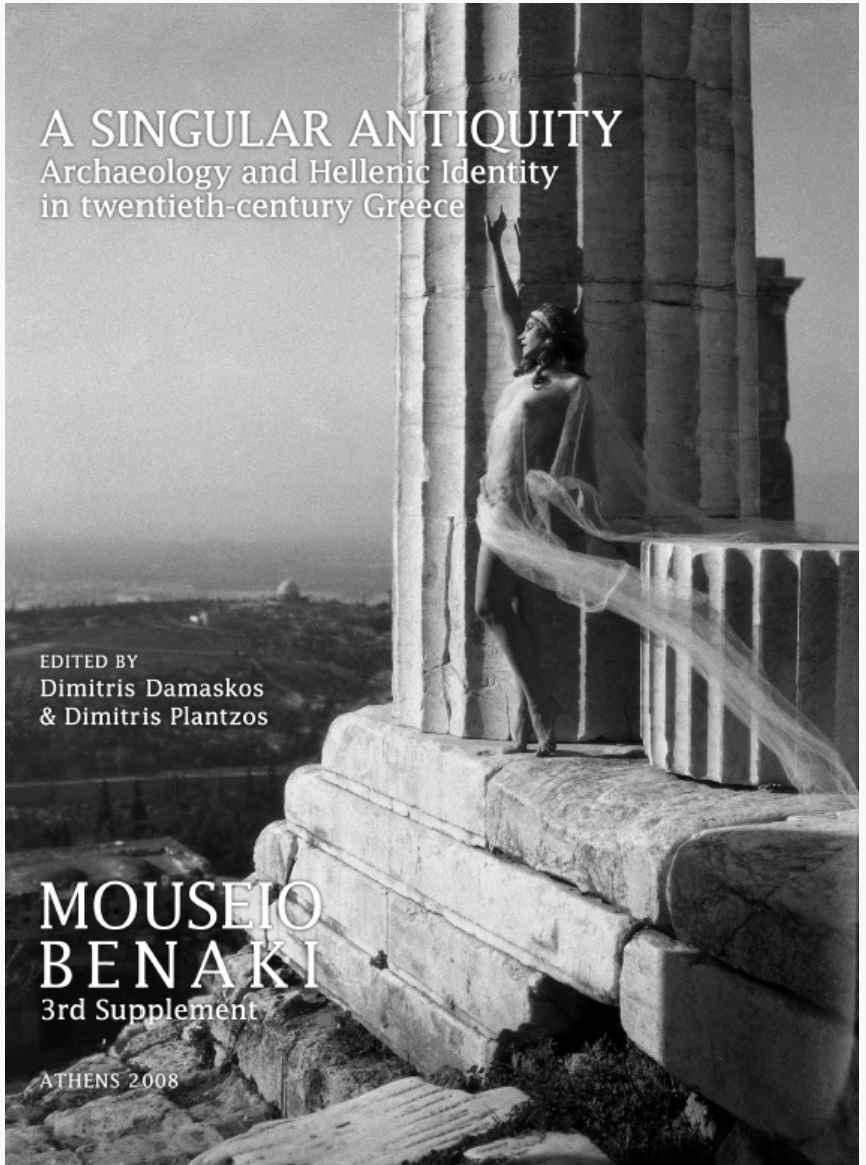

The excavation of the Ancient Agora of Athens: the politics of commissioning and managing the project

Niki Sakka

doi: $10.12681 /$ benaki.17981

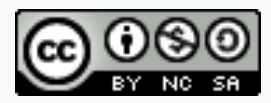

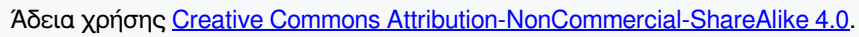

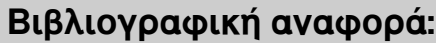

Sakka, N. (2008). The excavation of the Ancient Agora of Athens: the politics of commissioning and managing the

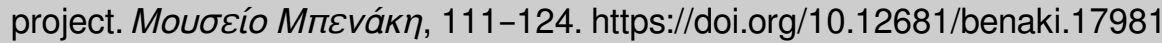




\section{The excavation of the Ancient Agora of Athens: the politics of commissioning and managing the project}

From THE MOMENT ATHENS was named capital city of the newly founded Greek state in 1833, there were persistent demands from Greek archaeologists, historians, architects, and town-planners for the Agora to be excavated. Politicians too dreamed of this. ${ }^{1}$ The evidence of the ancient literary sources, ${ }^{2}$ later supported by the results of small-scale excavations, conducted by the Greek Archaeological Society and the German Archaeological Institute from the middle of the nineteenth century onwards, revealed the unequivocal importance of the site for our understanding of the archaeology and topography of Athens (fig. 1).

In the second decade of the twentieth century, after the Greek military defeat in Asia Minor and the relinquishing of the 'Great Idea' with the consequent emphasis on redefining and promoting Greek cultural specificity (Hellenicity), the issue of discovery, enhancement and display of ancient Athens was elevated to a duty for a nation that, in essence, owed its very existence to its past and at the same time to a means of demonstrating its civilized status. Given this particular set of historical circumstances and assumptions, the area of the ancient Agora had to be 'purified' of its modern buildings, set apart from its surroundings, investigated and promoted as a national site of great symbolic value. ${ }^{3}$ In April 1921, indeed, A. Philadelpheus submitted a memorandum to the Third National Assembly requesting approval for the funds required for the expropriation and excavation of the ancient Agora, on the occasion of the forthcoming centenary celebrations of Greek independence to be held in $1930{ }^{4}$

At a political level, from as early as the second decade of the twentieth century, measures were taken towards the rehabilitation of urban centres, by settling disputes concerning real estate ownership and by exercising control over land use. Several pieces of legislation on town planning were introduced and remodelling schemes emerged. ${ }^{5}$ In the context of this politically justified trend towards modernization, decisions affecting the historic fabric were taken, including reviving the Agora issue, which by that time had reached a critical state. ${ }^{6}$ The inherent weaknesses of the Greek administration (bureaucracy, incoherent implementation of laws, political compromises) had contributed to a gradual contraction of the zone around the Acropolis, which was free from later buildings and reserved for archaeological excavations. ${ }^{7}$ In the aftermath of the Asia Minor Catastrophe in 1922 with the subsequent massive influx of refugees, resulting in strong pressure to find (or build) housing in the heart of Athens, there was an imminent risk of ending up with a completely built-up area in the Agora, thus eliminating any chance of future archaeological investigations. The Greek Minister for Public Instruction, R. Livathinopoulos, admitted that 'those who had formerly been quietly waiting for their houses to be bought [...] began to demand insistently that either their properties be bought immediately or they be given permission' to build new houses. 'Their boisterous protests have assumed [...] an almost revolutionary tone'. ${ }^{8}$ Faced with these problems, which were exacerbated by the tight state budget and the prohibitive expenditure required for expropriations ${ }^{9}$ the Government, despite its original intentions, relented and granted new building permits, in an attempt to relieve 
the social tension. But after a fierce reaction from the Greek Archaeological Service, the Government's decision was temporarily suspended, ${ }^{10}$ confirming the prestige and social influence of the archaeologists. At any rate, if the comprehensive blocking of the excavation of the civic, economic and religious centre of ancient Athens was to be averted and the distinctive remnants of an ideologically approved past were to be displayed, the issue of property rights had to be regulated once and for all and a large section of the historic urban centre had to be cleared.

The only feasible solution, if such an extensive and expensive enterprise were ever to be organized, was to appeal to the foreign archaeological schools. At a time of severe global economic recession, the American School of Classical Studies at Athens (hereafter ASCSA) was the only one to respond promptly. ${ }^{11}$ Its decision to undertake the ambitious project was completely consistent with its research profile, its official focus on the study of classical civilisation and the wish to control the interpretation of this most distinguished archaeological field. ${ }^{12}$ It was further motivated by the school's inter-war goals, which ranged from the educational and scientific expansion of the institute to the strengthening of its prestige and power both in Greece and abroad. Indeed, its involvement in the Agora excavation, as emerges from the correspondence of its officers, was set against a background of academic rivalry. The ASCSA saw it as a means of promoting itself at international level and as an attempt to contest European dominance, by counterbalancing the successes of the French School at Delphi and Delos, of the German Archaeological Institute at Olympia, and of the British School at Knossos. ${ }^{13}$ Moreover, the ASCSA as the main trustee of both portable and non-portable finds from a highly important site, the cradle of democracy, would become a training ground for archaeologists and architects who, on returning to their native land, would form the nucleus of American Classical studies: 'Not only is this area the richest in promise of discovery of any that exists in Greece, but [...] we shall be able to develop a body of trained scholars in all diverse fields of Classical Antiquities and provide them with material for many years of work of the highest significance for our future knowledge of the ancient civilization of Greece.'14

The American press was a valuable ally sharing in and encouraging the School's expectations as regards the po- tential assignment of the excavation. E. Capps, Chairman of the Managing Committee of the ASCSA from 1919 to 1939 , remarked that 'with the single exception of the discovery of the tomb of Tut-ank-amen in Egypt last year [...] no topic of archaeological interest has aroused such widespread and favourable comment in the American press as this project of the excavation of the Athenian Agora by the American School'. ${ }^{15}$

Positive comments on the anticipated moral benefit of the project in leading journals increased the fame of the School, at the same time reviving popular interest in the Greek past, against constant inter-war statements concerning current devaluation of the status of classical archaeology in American education and culture. ${ }^{16}$ In addition, all this publicity acted as an extremely effective way of attracting the private capital on which the ASCSA relied to cover its operational and research costs.

In an even broader context, given the established notion that acknowledged culture as a way of bridging the communication divide between two peoples, such a promising research programme may have represented, in a small way, a means of increasing American economic influence in Greece. At a period when Greek-American commercial relations were rapidly expanding and American investment capital was becoming involved in the construction of Greek public works, such as the Marathon waterworks, ${ }^{17}$ it seems reasonable to associate the excavation of the Agora and the success of the fundraising drive organized by the ASCSA with American economic policy. The profit expected from this conversion of cultural into material capital (in the sense investigated by Pierre Bourdieu $)^{18}$ was stressed by the British ambassador to Athens, L.T. Henderson, in an official document making suggestions as to the benefit of British prestige in Greece with reference to the American example: 'the Americans realize the prestige that archaeologists' work brings in countries which, like Greece, Italy and Egypt, are proud of their past and their rich men give generously with the result that the American School is better equipped than ours and doesn't have to decline work owing to lack of money'. ${ }^{19}$

Besides the expected accumulation of material wealth, in an era of change and challenge to the existing order, the American elite, by supporting the Agora project, and thus classical archaeology, was affirming a traditional code of values in the face of Bolshevism and the Bau- 


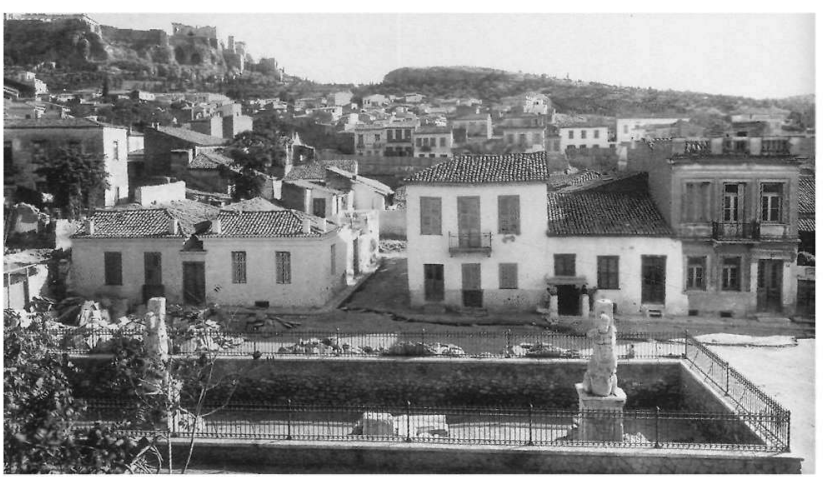

Fig. 1. View of the Stoa of the Giants in 1935, image: 2008.18 .0016 (photo: American School of Classical Studies at Athens: Agora Excavations).

haus. ${ }^{20}$ Further ideological propaganda benefits were anticipated from the fact that a democratic state with a long history of Philhellenism was exploring the birthplace of democracy, at a time when Mussolini's regime was using archaeology and large-scale excavations in the imperial fora to establish connections between Fascism and ancient Rome. ${ }^{21}$

It was, probably, in this general spirit that J.D. Rockefeller decided to support this promising enterprise financially, having been persuaded both of the wide appeal of the Agora excavations and of the great importance of the expected finds. In addition, the ASCSA's organisational skills and its experience in mobilizing human and financial resources to create a stimulating and productive atmosphere ${ }^{22}$ must have confirmed his decision since they could guarantee the conversion of his invested economic capital into symbolic capital. ${ }^{23}$

Official negotiations to draw up an agreement that would regulate the terms of the excavation were entered into with the Ministry of Public Instruction in 1927. ${ }^{24}$ Edward Capps, a dynamic key-figure in the undertaking of the project, very influential with both Greek and American political and economic circles and a close associate of Venizelos, ${ }^{25}$ led the negotiations, assisted by $\mathrm{R}$. Carpenter, the Director of the ASCSA, A. Kyriakidis, counsel and legal adviser to the Agora project and A. Adossidis, its Business Manager. ${ }^{26}$ The main representative on the Greek side was Konstantinos Kourouniotis, Director of the Archaeological Service from 1925 to
1933. J.D. Rockefeller, who remained anonymous for a considerable time, ${ }^{27}$ was also involved in the management of the project, though indirectly. As the main sponsor, he considered it his self-evident right to be kept informed 'about the attitude of the Greek Government, that of the property holders in the Agora district, the results of the first expropriations, the organization set up for the various parts of the undertaking and the plans as they develop for the actual work of excavation.'. ${ }^{28}$ Thus, even Capps occasionally attempted to conceal developments that would have had a potentially negative effect on Rockefeller's decision to fund the excavations. ${ }^{29}$

On 8 August 1927, the Greek Minister of Public Instruction, M. Argyros, granted the School the concession no. $35464 / 1239$ to excavate the part of Athens 'which is bounded on the south by the Acropolis and the hill of the Areopagus, on the west by the elevation on which the Theseum stands from the Areopagus to the entrenchment of the electric railway, on the north by the entrenchment of the electric railway as far as Monastiraki and from there by the southern side of Pandrosus street until its junction with Aeolus street and on the east by a line beginning at Aeolus street at the point where it is joined by Pandrosus street and continuing straight to the Acropolis'. ${ }^{30}$

Despite Capps' expectations, ${ }^{31}$ the permit was not accepted immediately. The Trustees of the ASCSA refused to countersign a concession ${ }^{32}$ that would oblige the institution to expropriate, section by section over a period of five years, the entire site to be excavated - a total of 577 structures, housing almost 8000 individuals. ${ }^{33}$ On the one hand, this would require exorbitant sums of money. On the other, it would create a huge amount of tiresome administrative work, enough to absorb the entire energies of the School staff and reduce significantly the time that, otherwise, would have been devoted to carrying out purely scientific work. ${ }^{34}$ On top of that, the permit indirectly obliged the School to complete the excavations once it had undertaken them. A commitment of this kind, however, was irreconcilable with one of the basic conditions set by Rockefeller for his funding of the project. Indeed, through a letter from his representative, A. Flexner, he had declared his active interest in the undertaking and his intention of providing the ASCSA immediately, as an indication of good faith, with the sum of $\$ 25,000$, which he judged sufficient for the finalizing of the agreement with the Greek government. However, 
an additional sum of $\$ 225,000$ would be placed at the disposition of the School only if it could conclude an arrangement that would secure its right to withdraw from the concession under certain contingencies. ${ }^{35}$ According to the donor, this condition would ensure, independently of any potential political unrest, the unstinting co-operation of the Greek state in surmounting complex management issues, conflicting interests including expected resistance from the landowners and second thoughts on the part of the centralized bureaucracy. The Minister of Public Instruction, however, could hardly concede in writing to grant the School according to the resolutions passed by the Trustees ${ }^{36}$ the right to proceed gradually, over a period of 25 to 30 years, to expropriations of those sections selected each time for excavation and to withdraw, if necessary, from the project. Such terms would entail the risk of social unrest caused by intensifying the sense of uncertainty among the inhabitants of the district. A new cycle of negotiations began.

The excavation of the Agora was evolving into a complex matter of major importance, not only for the Greek state, but also for the ASCSA and E. Capps, who had been commissioned to carry out the task. After the wide publicity that the affair had received, failure to conclude the necessary agreement would severely undermine the academic prestige of the School, and would naturally call into question the competence of all those who had been actively involved in the project. ${ }^{37}$

Capps was fully aware of the ASCSA's negotiating strength, which derived from the political and economic dependence of this small state on the Great Powers, and did not hesitate to use this political capital ${ }^{38}$ in order to secure an amendment to the terms of the permit, issued on 8 August 1927..$^{39}$ Thus, he decided to acquaint both the Greek minister plenipotentiary in Washington, Ch. Simopoulos, and the Under-Secretary of State of the United States, Colonel R.E. Olds, with all the details, asking at the same time for their concerted support. At the conference held on 21 January 1928 in Washington, Simopoulos admitted that cancellation of the agreement with the School 'would seriously affect the standing of Greece in America', ${ }^{40}$ at a period when negotiations were still in progress for the conclusion of the second refugee loan, the approval of which required ratification by the American Congress. ${ }^{41} \mathrm{He}$, therefore, agreed to make the strongest possible representations to his foreign minister,
A. Michalakopoulos. Colonel Olds of the State Department, on his part, promised to ask the United States ambassador to Greece, R. Skinner, to stress the Department's profound interest in the enterprise, 'as bearing upon the relation of the two countries and to urge the favourable consideration' of the proposed modifications to the concession. ${ }^{42}$

On 30 January 1928, Capps wrote to Kourouniotis, communicating the results of the above mentioned conference with the officials of both countries, stressing at the same time, the political and academic impact of a possible breakdown in the negotiations. In a further effort to strengthen his hand, Capps linked the effective and cordial Greek-American co-operation in the Agora project with the prospect of new American financial grants to the Archaeological Service for the administration of museums and sites, the conducting of excavations and the execution of restoration and conservation work. The proposal was tactfully expressed to avoid offending the Greek archaeologists. To this end the American intervention was justified as a small token of interest in Greek archaeology, indicating America's recognition of the manifold problems of maintenance and management of the great bulk of material remains dispersed throughout Greece. ${ }^{43}$

Given the fact that after the Asia Minor Disaster, the Greek state relied on foreign lending for the achievement of its goals - that is, the economic rehabilitation of the country and the securing of the revenues required for the maintenance of the army and the integration of the refugees ${ }^{44}-$ it is obvious that even minor issues such as the terms for an excavation permit required delicate handling. Thus, 'through the very kind offices of $\mathrm{Mr}$ Skinner', in the words of E. Capps, and due perhaps to 'the very urgency of the question, the Greek Minister has come around' to the ASCSA's 'view of the case, ${ }^{45}$ although this created injustices, admitted even by the American ambassador in Athens. ${ }^{46}$

On 8 August 1928, the government of E. Venizelos granted a new concession, which envisaged, at the School's suggestion, ${ }^{47}$ the reduction of the area to be expropriated and investigated by the Americans. Thus, the territory of the initial permit of the previous August was to be divided into two parts that would be simultaneously excavated, the western part, up to the Stoa of Attalos, by the Americans and the eastern part by the Greek Ar- 


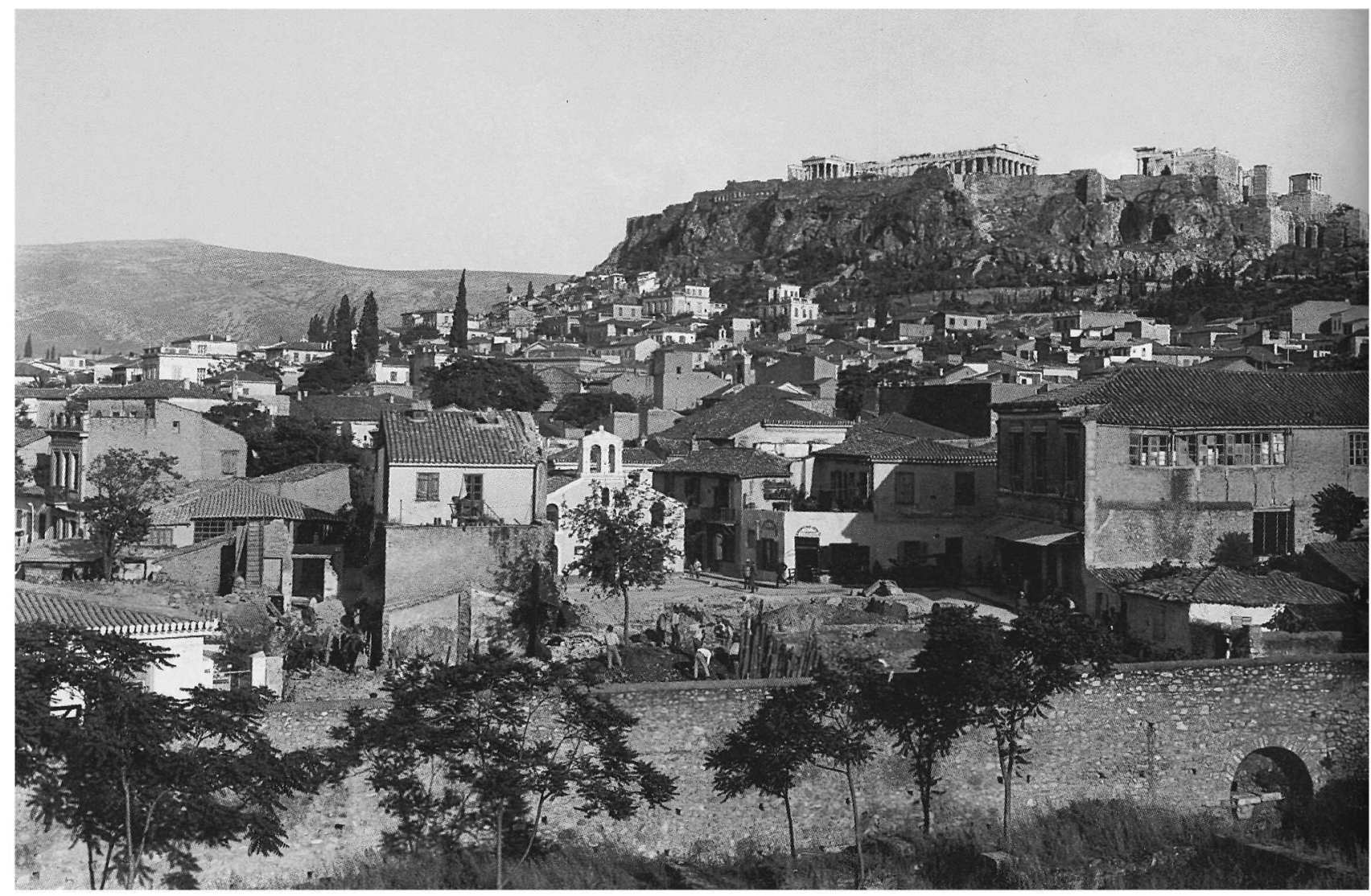

Fig. 2. View of the Agora on the first day of excavations, image: 2008.18.0005 (photo: American School of Classical Studies at Athens: Agora Excavations).

chaeological Service. ${ }^{48}$ This new agreement was intended to facilitate negotiations, since by reducing the American zone and subsequently the predicted duration of the excavations, social pressure was likely to become less intense. The Trustees accepted the Greek Concession under the officially communicated understanding that the School regarded its right to withdraw as inherent in the undertaking. ${ }^{49}$

Another three months passed before the Minister of Public Instruction, K. Gontikas, informed the Director of the ASCSA, R. Carpenter, that work had begun on drafting the legislative framework of the excavations, according to the principles already agreed upon with the School..$^{50}$ The Decree, in the preparation of which representatives of the ASCSA had participated, was issued on the proposal of the Cabinet with the current opinion of the appropriate Parliamentary Committee and was published in the Greek Government Gazette on 23 March 1929.51
One of the basic terms was the successive expropriation of properties by sections, depending on the progress of the work, over a period of ten years, the length of time predicted for the excavations (Articles 3 and 8). According to a verbal statement, made by $\mathrm{K}$. Gondikas, this was purely a token clause since once the time limit had expired it could be automatically renewed. ${ }^{52}$ The same Decree enforced a ban on major or minor alterations to the existing edifices for the ten-year period (Article 2). The task of assessing the indemnities was assigned to a Committee of Evaluation, which was not allowed to accept verbal testimony (Article 12). Instead, it had to base its work on actual documentary evidence (Article 24), such as tax returns, which, in practice, guaranteed the best protection for the ASCSA, given that taxpayers tend to declare the lowest possible income and to minimize the value of their real estate. The Decree was, rightly, criticised fiercely by the press, while there was a considerable outcry among 


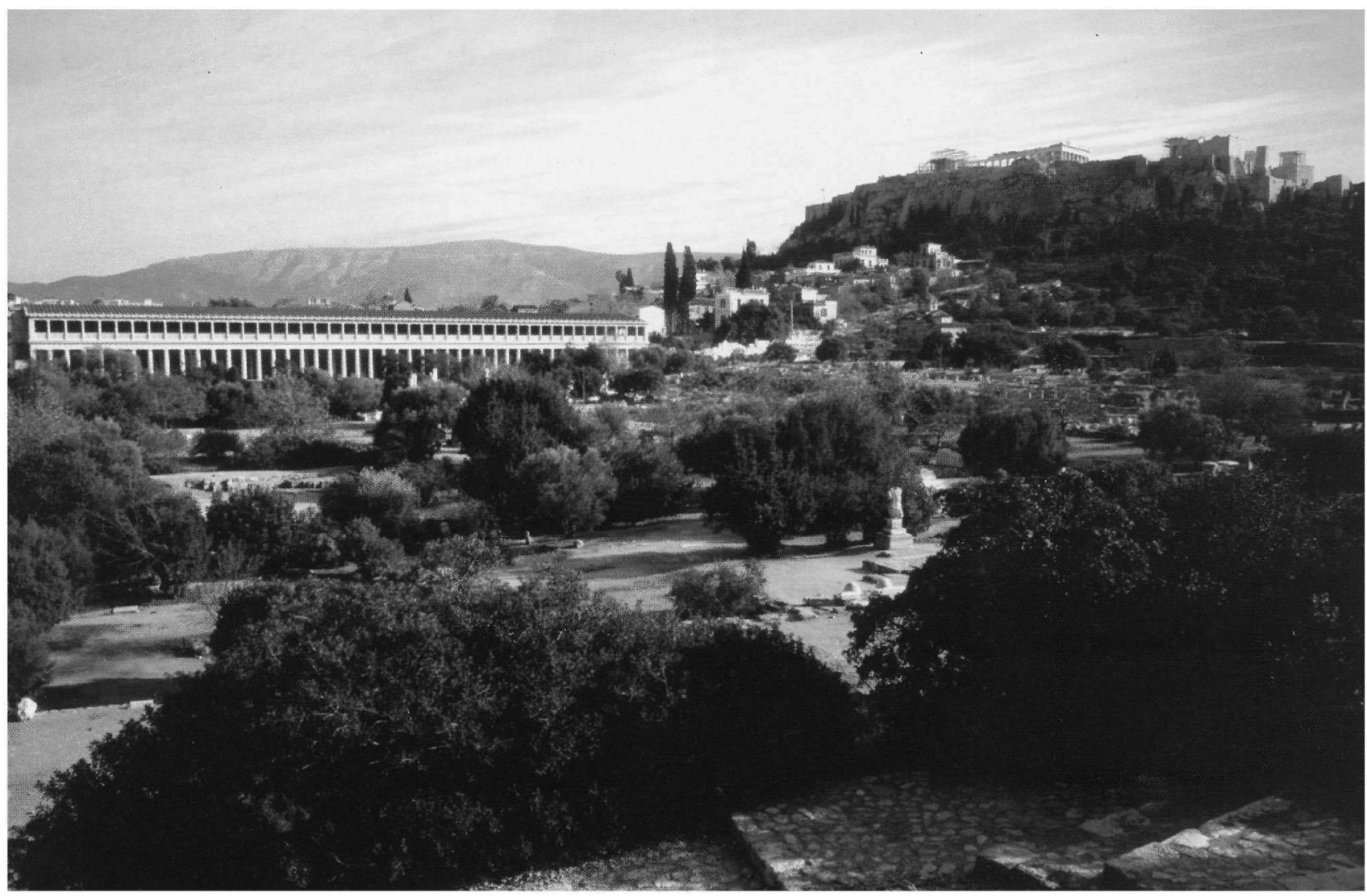

Fig. 3. View of the Agora 75 years later, image: 2008.18.0008

(photo: American School of Classical Studies at Athens: Agora Excavations).

the local residents, who formed the Association of Renters of houses and shops and the Owners' Committee for their better representation.

It is worth noting, at this point, that what was disputed, at least by the official delegates of the residents, was not the actual need to carry out the excavations but the legal framework for this. ${ }^{53}$ Thus, at a meeting of the property owners, J. Alibertis, a member of their Committee, boasts of their ancient heritage, while expressing at the same time bitterness, and frustration at state indifference and insensitivity to the citizen's complaints:

'The people who first settled in Athens, this intellectual aristocracy of Athens [...] cannot fail to appreciate the importance and the necessity of the archaeological excavations. They are not, therefore, opposed to them. They are opposed, however, with the whole of their heart, to the way in which the indemnities are determined by the De- cree, which legitimises the confiscation of their property in a manner that could not have happened even in the medieval period and in a badly administrated state. ${ }^{54}$

Given the sentimental attachment of the residents to the homes where they had lived for years, and the general problems arising out of the compulsory purchase orders, particularly at a time of housing shortage, one would have expected them to resist eviction from their homes and the general area. The owners' representatives, however, seemed to acquiesce in the enhancement and promotion of the ancient ruins and simply required state intervention in renegotiating the terms of expropriation and the protection of their economic interests. Had they internalized the official rhetoric on the uniqueness and the major importance of the 'area around the Acropolis, whose treasures', according to the Minister of Public Instruction, Gontikas, 'belong to history, to scholarship, 
to the entire world?'55 Or having realized that the excavations were apparently inevitable, were they seeking to conform, at least superficially, to dominant stereotypes, to demonstrate their affiliation to the cultivated classes, taking explicit exception only to state insensitivity? It is equally possible that their assent was due to a widespread feeling of insecurity about the fate of their living quarters and the uncertainties arising out of the long-term 'freezing' of their properties and their unsatisfactory dealings with the Greek public authorities.

In the same spirit, the daily press did not argue for the preservation of the urban agglomeration, considering it more important that efforts should be made to rescue from 'the depths of the centuries, all tangible information about the life, art and culture of ancient Greece [...] before the astonished eyes of the civilized world'.$^{56}$ Although there were reports of 'protests on sentimental grounds' for the loss of 'sweet, old Athens', ${ }^{57}$ (fig. 2) the vision of an archaeological park prevailed, ${ }^{58}$ of an area planted with trees (fig. 3), 'rather like the Forum or the Palatine Hill in Rome, ,9 $^{5}$ an Athens that would be 'liberated, cleaned up', would 'breathe again' after the demolition of the 'miserable, unhealthy, ramshackle houses and huts ${ }^{30}$ and a proper display of the ancient city 'with its streets and buildings ${ }^{6}{ }^{61}$ Accordingly, the protests of the press were concentrated on the economic interactions, inveighing against the terms of a decree that was permitting 'the unheard of, unprecedented plundering of private property ${ }^{362}$ and against the unconstitutional stance of the Greek government, which 'had allowed itself senselessly and in a most undignified manner to be subjugated to the American School'. ${ }^{63}$ It was a debate in which the tone was set by local resentment against the neo-colonial attitude of the ASCSA. American archaeologists were accused of exhibiting exploitative behaviour towards the local residents and being indifferent to their present-day needs in order to reveal the accomplishments of a revered past. ${ }^{64}$

Overcoming these objections and settling the matter in accordance with the demands of the School depended, as Adossidis had observed in the past, ${ }^{65}$ entirely on the then Greek Prime Minister, Eleftherios Venizelos, who once more supported powerfully the Agora project. In fact, even though the Decree of 23 March 1929 was introduced to Parliament for ratification just before the elections for the Senate, Venizelos, anxious to avert the wrecking of the undertaking, ignored the potential po- litical cost of passing a law that demonstrably affected the interests of a large number of voters. In spite of the stern resistance from the parliamentary opposition and local residents, he insisted on voting the law including the amendments, suggested by the School for its own benefit. ${ }^{66}$ For instance, provisions such as the appointment of two representatives of the ASCSA ${ }^{6}$ instead of one ${ }^{68}$ on the Committee of Evaluation, guaranteed that American economic interests would be secured. ${ }^{69}$ That amendment, submitted by Adossidis to the Greek Minister of Public Instruction ${ }^{70}$ in a letter written soon after the publication of the Decree in the Government Gazette, was accepted by the Parliament in the course of the debate over Law 4212.

Law 4212 was voted by the Parliament and endorsed by the Senate in July 1929. A number of essential additions and amendments were passed in April 1930,11 at which date the negotiations essentially came to an end, five years after they had began, while actual excavation work started the following year (figs 4-5). Having secured a favourable legislative framework, the ASCSA tried to further facilitate things through initiatives such as a donation of $\$ 10,000$ to the Greek State ${ }^{72}$ on the formally communicated condition that the Archaeological Service should proceed to expropriations in the Greek zone prior to the ASCSA taking any such steps in their zone. The aim was 'to save a good deal more than the amount of the investment ${ }^{73}$ since the usual practice of the state offering low indemnities in cases of compulsory expropriations in the interest of a public cause would constitute a precedent and would have later the effect of bringing down real estate prices in the American zone. ${ }^{74}$ To the same end, Capps in an attempt to develop closer relations with the Greek archaeological authorities, accepted Kourouniotis' request to find funding for his excavation at Eleusis. ${ }^{75}$ More specifically, in a personal letter to Capps, Kourouniotis formally applied for 'American assistance' since his work at Eleusis was progressing 'frightfully slowly as the money, which the Archaeological Section was able to place at' his 'disposal', was 'ridiculously little'. ${ }^{76}$ Capps took up the matter informally with the Rockefeller Foundation making clear that while the excavation itself is unquestionably a highly important one and being carried out and brought to publication in the most scientific way, yet from the American point of view its chief importance at the present moment lay in the fact that Dr Kourouni- 


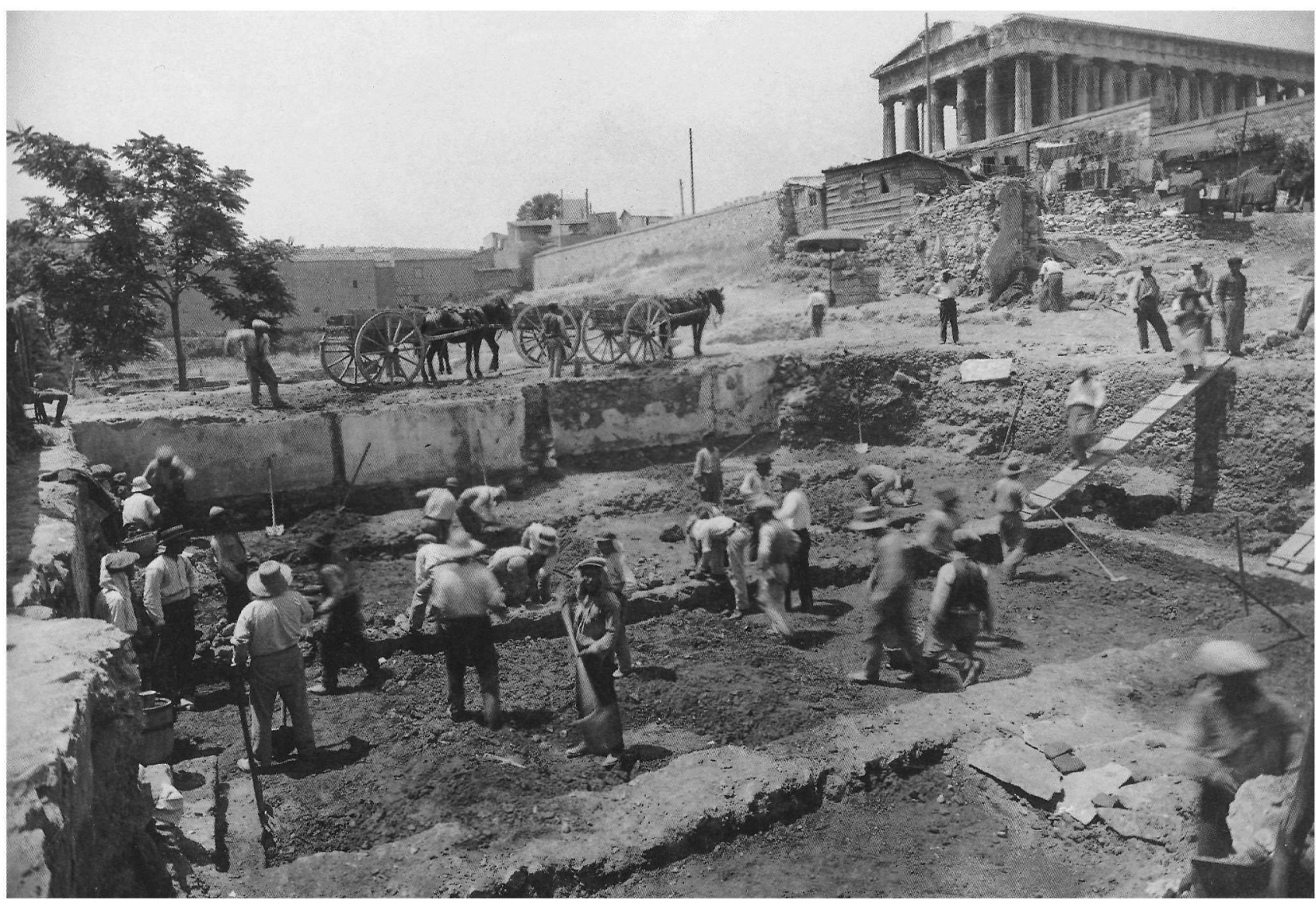

Fig. 4. View of the west side of the Agora, 19 June 1931, image: 2008.18.0004 (photo: American School of Classical Studies at Athens: Agora Excavations).

otis, through his official position, is the officer of the Greek Government on whom devolve all the work and many of the decisions in connection with the projected American excavation of the Athenian Agora'.77

The Rockefeller Foundation, however, having not at that time formulated a policy regarding support of excavations, could not sponsor the Eleusis project 'on its intrinsic merit'. So, Capps turned to Rockefeller asking him, through A. Woods, 'to finance Kourouniotis' excavations at Eleusis through School's instrumentality' ${ }^{78}$ a proposition that was finally adopted..$^{79}$ So, Kourouniotis was receiving the grant of $\$ 10,000$, made over a four-year period while he was a member of the Agora Committee of Evaluation. And perhaps we should not overlook the fact that when G. Papandreou, Gontikas' successor at the Ministry of Instruction, attempted, under pressure from the local property owners, to have Law 4212 amended and, inter alia, to replace Kourouniotis with a civil engineer working for the state, the School resisted very strongly. ${ }^{80}$

The socio-economic problems arising out of the implementation of Law 4212 were outlined by Adossidis himself in a letter to Capps: at a time of economic crisis, residents in the area of the Agora, most of whom were 'poor people who struggled to make a living', could not liquidate their real estate. They could find no private purchasers for their houses, nor could they take out a mortgage on them as long as the question of expropriation remained in suspense, since no potential buyer or creditor knew either the exact amount of the compensation or when it would be paid. Considerable anxiety was generated by the ban imposed on even minor repairs to buildings, since even in cases where the repairs were absolutely essential the owner had to sign that he would not subsequently ask for greater indemnity. ${ }^{81}$ What is 


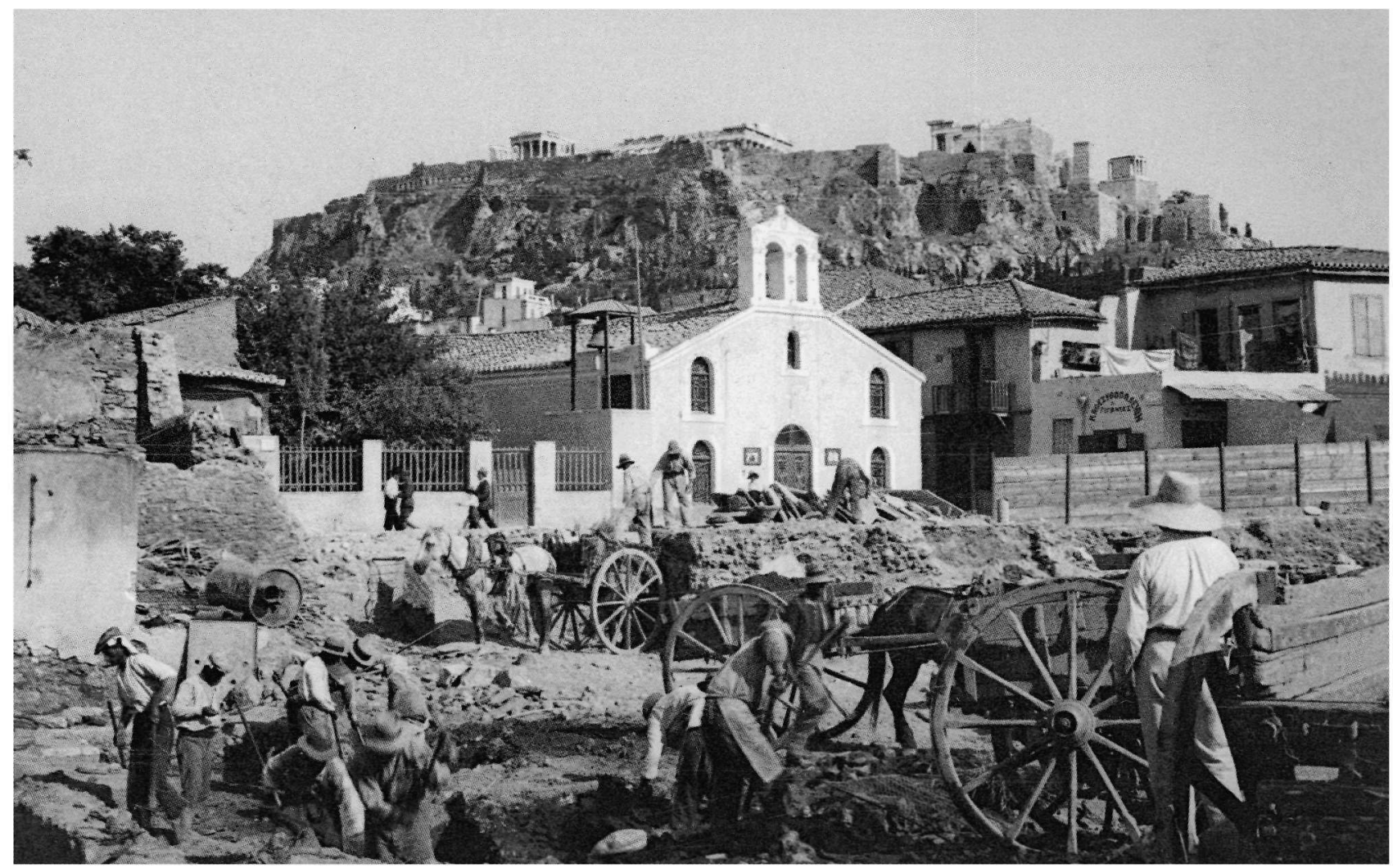

Fig. 5. View across Section E with church of Panagia Vlassarou in the center, image: 2008.18.0033

(photo: American School of Classical Studies at Athens: Agora Excavations).

more, the appraisals of the buildings and the final assessment of the indemnities were, as expected, 'very favourable' to the ASCSA. ${ }^{82}$

The archaeological investigation of the Agora was a duty incumbent on the Greek government. After many setbacks the issue which had been pending for almost a century was settled with the consensus of both scholars and the wider public. Acting as the guardian of national values the state had to convert this residential area into an archaeological site, which would subsequently become a tourist attraction, in a period when organized tourism was appearing for the first time in Greece. ${ }^{83}$ As Doris notes, however, it is a firm principle of law that, if restrictions of any kind are imposed upon the rights of the individual for the public benefit the burden must fall not on the individual but on the state and the society. ${ }^{84}$ In the case of the Agora, the state neither possessed the financial infrastructure to respond properly to its obligations to the landowners, nor the political will to do so. It assigned the project without any real preparation or thorough assessment of the social consequences, and without trying to integrate it into a comprehensive planning strategy. Decisions relating to an area declared monumental (according to Herzfeld's term) ${ }^{85}$ by the state were taken within a volatile political and economic climate, in the shadow of limited state revenues and of the unavoidable risk that, in the existing circumstances, the archaeological exploration of the Agora would have to be completely suspended if foreign financial support were not forthcoming.

It was these same priorities shaped by long established national ideologies and individual preconceptions that unquestionably influenced the choices of the Greek archaeological community. ${ }^{86}$ Greek archaeology, as many scholars have already pointed out, was involved in the 


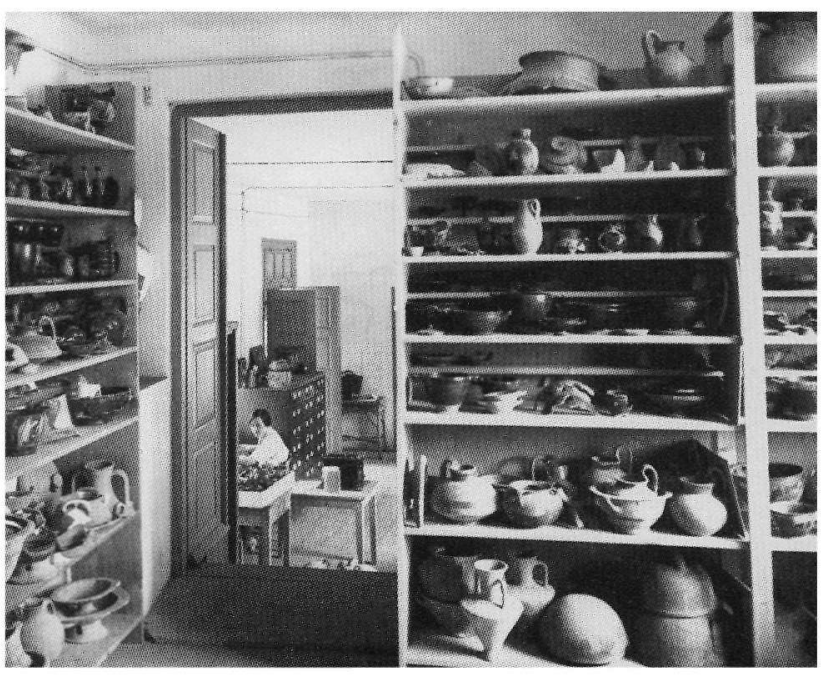

Fig. 6. Lucy Talcot by the pottery storage in the Old Excavation house, image: 2008.18.0279 (photo: American School of Classical Studies at Athens: Agora Excavations).

nation's ideological battles from the moment it became an official branch of scholarship. ${ }^{87}$ Seen as a tool in the ambitious project to document the racial and cultural continuity of the Greek people, it was called to assist in the shaping of Greek national identity, largely through the enhancement and promotion of the classical past. Against this background, at a time when archaeological policy stressed the protection of antiquities and the emphasis was on the investigation of major sanctuaries and public spaces in city-states, the civic centre of Athens had to be excavated at any cost. In this context the Archaeological Service, the University, and the Archaeological Society approved the assignment of the investigations to the ASCSA on the sole condition that Greek archaeologists should participate in the project. The only thing they were anxious to negotiate about was what proportion of the Agora excavation staff they should represent. ${ }^{88}$ There was no debate on theoretical or methodological issues, no awareness of the problems arising from the disintegration of the area's social fabric. Although in cities with a long continuous history, care for antiquities has to be balanced against sensitivity to the needs and lives of the inhabitants, both Greek political and archaeological authorities and the ASCSA, failed to take into account the social dimensions of the enterprise in their anxiety to carry out the excavations. According to Carpenter, it was 'a question whether a few thousand dwellers have the moral right to hide from the eyes of the whole civilized world the antiquities in which so many millions of people are vitally interested' ${ }^{89}$

Scholarship proceeded at the expense of a large group of citizens, whose demands were not sufficiently considered, despite their constant, intense protests, involving articles in the daily press, the submission of memoranda to Parliament, the Senate and the ASCSA, and protests to the American Embassy..$^{90}$

The Agora excavations gradually expanded into one of the most important archaeological projects of the interwar years. They brought to light a diversity of notable monuments and a vast number of artefacts, attained a high degree of knowledge about the layout of the ancient civic centre of Athens, were carried out with meticulous attention to detail and stratification, promoted a far-sighted system of recording and classifying all the evidence and were followed up by a series of collective publications that still form a valuable tool for scholarship (fig. 6). At the time when the large-scale American investigations were initiated, the vision of recovering the remains of an idealized Greek past was stronger than the need to preserve the living historic centre. It was not until recently that the issue of the priority of antiquity over the recent past and the present has become a focal point for controversy and the idea of excavating the whole area on the north slopes of the Acropolis has been abandoned. ${ }^{91}$

In a shifting present, modern perceptions of the past and management strategies for heritage sites are constantly reshaped with regard to the changing political, economic, ideological and cultural scene..$^{92}$ Power relations, political and national priorities are still intervening in the construction of knowledge and the practice of the discipline but everyday social exigencies are less frequently being overlooked. However, recent awareness and criticism of the role of the archaeological institutions and of the impact of current, individual and collective bias, needs and expectations on the inherited past facilitate not only a deeper understanding and appreciation of that past but also the greater enhancement of its physical remnants.

\section{Niki Sakka}

3rd Ephorate of Prehistoric and Classical Antiquities Hellenic Ministry of Culture nsakka@hotmail.com 


\section{Notes}

* I sincerely thank N. Vogeikoff-Brogan for facilitating my access to the Archives of the American School of Classical Studies at Athens while preparing my doctoral thesis, part of which forms this paper; and E. Sikla who helped me search the Administrative Records of the American School. I would also like to thank S. Dumont, Registrar of the Agora Excavations for the photographic permissions, S. Dandou, K. Mandeli and especially E. Yalouri, who read and commented on an earlier draft. I am also grateful to J. Davis not only for his valuable comments on the text but also for bringing to my notice the relevant documents from the Archives of the U.S. State Department and from the Rockefeller Archive Center.

1. ASCSA, Administrative Records, The Minister of Public Instruction R. Livathinopoulos to the Dean of the University of Athens, 11 December 1925, n. 56957/2429; Biris 1966, 30; Travlos 1993, 250-55; Mallouchou-Tufano 2001.

\section{Pausanias I, 3-17.}

3. On the 'purification' of the Acropolis and the surrounding inhabited area see Yalouri 2001; Caftanzoglou 2001. 165.

4. Philadelpheus 1994, 188-89; Mallouchou-Tufano 1998,

5. Karadimou-Yerolympou \& Papamichos 1992.

6. Biris 1966, 282-84.

7. Biris 1966, 35; 61-62.

8. ASCSA, Administrative Records, The Minister of Public Instruction R. Livathinopoulos to the Dean of the University of Athens, 11 December 1925, n. 56957/2429.

9. According to a tentative estimate of the Ministry of Public Instruction the sum needed was a million dollars (ASCSA, Administrative Records, The Minister of Public Instruction R. Livathinopoulos to the ASCSA, 20 February 1926, n. 381). When the excavations were interrupted by the war in 1940 , the Agora Commission had spent more than a million dollars while 365 'undesirable buildings' had been demolished (Lord 1947, 244).

\section{As above n. 8.}

11. ASCSA, Administrative Records, B.H. Hill, Director of the ASCSA to the Minister for Public Instruction, 3 December 1924. Cf. ASCSA, Administrative Records, Memorandum for the President of the Greek Government as to the issue of the Excavation of the ancient Agora of Athens, 20 August 1928.

12. The School's scientific goals are summarized in a most clear way by its Director during the years 1927-1932, R. Carpenter: 'Our ultimate reason for existence must always and necessarily be the pre-eminence of things Greek over things un-Greek or pre-Greek or post-Greek. It is so far as we insist on this old faith of the Humanists in the humanities (and not in the pre-human-ities or even exhume-anities) that our School will have a torch to hand down to future days', ASCSA,
Administrative Records, Annual Report for the year 19271928 from R. Carpenter to the Managing Committee, May 1928.

13. ASCSA, Administrative Records, Notes for Mr Ybarra, no signature, no date (but certainly written in 1927).

14. ASCSA, Administrative Records, E. Capps to A. Flexner, 17 December 1926. Cf. Morris 1994, 34-35.

15. ASCSA, Administrative Records, B.H. Hill to the Greek Minister for Public Instruction, forwarding a communication written by E. Capps in the name of the Managing Committee of the ASCSA, 7 November 1925.

16. Dyson 1998, 158-60; Dyson 2002, 159-60.

17. Cassimatis 1988, 166-85.

18. Bourdieu 1977; Bourdieu 1990.

19. Public Record Office, F.O. 395/461, P 745/26/150, L. T. Henderson to R.A. Leeper, 15 March 1932.

20. Dyson 1998, 158-59.

21. Dyson 1998 179-84; Dyson 2006, 175-90.

22. ASCSA, Administrative Records, Memorandum of A. Woods to E. Capps, 15 December 1927. Note that in 1913, the Secretary of the Rockefeller Foundation, Jerome D. Greene, had written a memorandum in order to establish a framework for the Foundation's work. Among the major points was to 'make sure when going into a community with a gift that the community has "its own will [...] and its own resources, both material and spiritual" to meet the need, avoid gifts in perpetuity' (http://www.rockfound.org/about_us/history/19131919.shtml). Cf. Lord 1947, 194.

\section{As above n. 18.}

24. ASCSA, Administrative Records, E. Capps to K. Kourouniotis, 30 June 1927; E. Capps to the Minister for Public Instruction, 30 June 1927.

25. At the end of World War I E. Capps was appointed Commissioner of the Red Cross for two years and United States Minister for one year, during which time he played a leading role in the founding of Athens College, together with E. Venizelos. See Dyson 1998, 169; Davis 2003, 150-51; 157.

26. Adossidis 'was decidedly one of the most influential persons in Greece with Mr Venizelos' (ASCSA, Administrative Records, E. Capps to R. Carpenter, 9 November 1928) and according to Capps the only Greek who had connections with the Trustees and indirectly with the 'Rockefeller people' (ASCSA, Administrative Records, E. Capps to R. Carpenter, 1 March 1928). On A. Adossidis and his political influence cf. Lord 1947, 232; Davis 2003, 167-68 n. 1.

27. The Americans felt that, if it were known in Greece that Rockefeller was financing the expropriations, 'the prices of the property might be materially increased' (National Archives and Records Administration, United States of America 
(hereafter NARA), RG 59, 868. 927/87), K. Chorley (Rockefeller Center) to the Secretary of State, 5 October 1936.

28. ASCSA, Administrative Records, A. Flexner to E. Capps, 15 March 1927.

29. ASCSA, Administrative Records, E. Capps to A. Adossidis, no date (probably written by December 1929).

30. ASCSA, Administrative Records, Minister for Public Instruction, M. Argyros to E. Capps, 8 August 1927, n. $35464 / 1239$.

31. ASCSA, Administrative Records, E. Capps to the Minister of Public Instruction, M. Argyros, 9 August 1927; E. Capps to Judge W.C. Loring, 8 September 1927.

32. ASCSA, Administrative Records, Resolutions passed by the Trustees of the ASCSA, 7 January 1928.

33. ASCSA, Administrative Records, K. Kourouniotis to R. Carpenter, 4 October 1927.

34. ASCSA, Administrative Records, E. Capps to the Members of the Managing Committee, 15 October 1927.

35. As above n. 28.

36. As above n. 32.

37. ASCSA, Administrative Records, E. Capps to R. Carpenter, 28 May 1928; E. Capps to K. Kourouniotis, 24 April 1929.

\section{Davis 2003.}

39. On foreign archaeologists taking advantage of the political, economic and cultural influence their countries exerted over Greece in order to promote their own scientific work, see Kalpaxis 1990; Kalpaxis 1993.

40. ASCSA, Administrative Records, E. Capps to R. Carpenter, 26 January 1928.

41. Cassimatis 1988, 193-200.

42. As above n. 40.

43. ASCSA, Administrative Records, E. Capps to K. Kourouniotis, 30 January 1928.

44. Louvi 1992.

45. NARA, RG 59, 868. 927/75, E. Capps to Colonel R. E. Olds, 8 May 1928.

46. NARA, RG 59, 868. 927/74, R. Skinner to the Secretary of State, 9 March 1928.

47. ASCSA, Administrative Records, E. Capps to R. Carpenter, 1 March 1928.

48. ASCSA, Administrative Records, Resolutions passed by the Trustees of the ASCSA, signed by F.P. Fish, Secretary pro tempore, 6 October 1928.

49. ASCSA, Administrative Records, The Director of ASCSA to the Minister of Education, 20 October 1928.
50. ASCSA, Administrative Records, K. Gontikas to the Director of the ASCSA, 15 November 1928, no. 52721.

51. Decree 23 March 1929 (G.G. 113/A/23-3-1929), 'On the designation as archaeological site of a part of the city of Athens'.

52. ASCSA, Administrative Records, A. Adossidis to E. Capps, 9 February 1929.

53. I Akropolis, 20 June 1929.

54. I Akropolis, 25 February 1929.

55. Eleftheron Vima, 24 February 1929.

56. I Akropolis, 18 July 1930.

57. Eleftheron Vima, 10 May 1931.

58. Eleftheron Vima, 10 May 1931 and 19 January 1938; Illustration, 26 March 1932. Note that the landscaping of the site as an archaeological park after completion of the excavations was provided for in the relevant Decree of $23 \mathrm{March}$ 1929 (art. 3).

59. As above n. 13.

60. ASCSA, Administrative Records, A. Adossidis to E. Capps, 1 December 1928.

61. Eleftheron Vima, 10 May 1931. Compare the approach of A. Arvanitopoulos, Professor of Archaeology at the University of Athens, on the issue of archaeology and urban planning and the enhancement of the area to the south of Acropolis in relation to the A. Nikoloudis project for the construction of Law Courts on the site of the former Military Hospital at

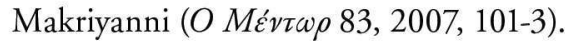

62. To Skrip, 5 March 1930.

63. I Akropolis, 18 July 1930.

64. Dyson 1998, 181-82.

65. ASCSA, Administrative Records, A. Adossidis to E. Capps, 23 February 1929.

66. Session 87-21 May 1929, Gazette of Parliamentary Proceedings, Period B', Assembly A', 843-47.

67. Law 4212, 16 July 1929 (O.G. 240/ A'/23-7-1929), art. 12. On the ratification of the 23 March 1929 Decree 'On the designation as archaeological site of a part of the city of Athens'.

68. As above, n. 51, art. 12.

69. ASCSA, Administrative Records, A. Adossidis to E. Capps, 26 September 1929.

70. ASCSA, Administrative Records, A. Adossidis to the Greek Minister of Public Instruction, 14 May 1929.

71. Law 4574, 26 April 1930 (G.G. 127/ A'/28 April 1930). On completion and amendment to Law 4212 'On the designation as archaeological site of a part of a city of Athens'. 
72. Cf. Stavropoulos 1930-31, 1.

73. ASCSA, Administrative Records, E. Capps to R. Carpenter, 18 June 1929. Note that the transaction was not to be made known to the property-holders.

74. ASCSA, Administrative Records, A. Adossidis to E. Capps, 31 December 1930.

75. On the quite intense relations between Kourouniotis and Capps in 1928, when the latter had been forced to pull out of the agreed joint excavation at Eleusis with B.H. Hill, former Director of ASCSA, see Davis \& Gorogianni 2005, 96-99.

76. Rockefeller Archive Center, I.I, Series 749, Box 4, Folder 34, Translation from the German of an excerpt from a personal letter from K. Kourouniotis to E. Capps, 15 September 1929.

77. Rockefeller Archive Center, I.I, Series 749, Box 4, Folder 34, E. Capps to Colonel A. Woods, 10 February 1930.

78. As above n. 77.

79. ASCSA, Administrative Records, A. Woods to R. Peabody, 6 March 1930; E. Capps to R. Carpenter, 15 May 1930.

80. ASCSA, Administrative Records, A. Adossidis to E. Capps, 12 March 1930; A. Adossidis to E. Capps, 17 March 1930.

81. ASCSA, Administrative Records, A. Adossidis to E. Capps, 8 February 1932.

82. ASCSA, Administrative Records, A. Adossidis to E. Capps, 10 December 1930; A. Adossidis to E. Capps, 20 De-

\section{REFERENCES}

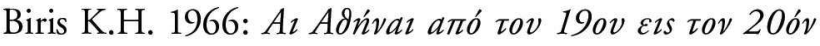
aıcúva (Athens).

Bourdieu P. 1977: Outline of a Theory of Practice (transl. by R. Nice; Cambridge).

Bourdieu P. 1990: The Logic of Practice (Cambridge).

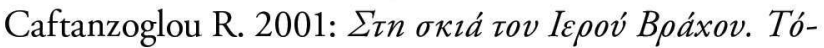

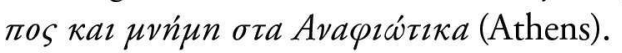

Cassimatis L.P. 1988: American Influence in Greece 1917-1929 (Kent, OH).

Davis J.L. 2003: A foreign School of Archaeology and the Politics of Archaeological Practice: Anatolia, 1922, Journal of Mediterranean Archaeology 16, 145-72.

Davis J.L. \& Gorogianni E. 2005: Embedding Aegean cember 1930.

83. Justification Report on the Bill 'On the designation as archaeological site of a part of the city of Athens', 12 February 1929.

84. Doris 1985, 251.

85. Herzfeld 1991.

86. Cf. article written by K. Kourouniotis in Estia, 15 December 1928.

87. Herzfeld 1982; Skopetea 1988; Kotsakis 1991; Morris 1994; Hamilakis \& Yalouri 1996; Kotsakis 1998; Hamilakis 1999.

88. ASCSA, Administrative Records, Archaeological Society at Athens to the Ministry for Public Instruction, 11 December 1925, n. 127; K. Kourouniotis to E. Capps, 25 June 1927; Archaeological Society at Athens to E. Capps, 12 July 1927, n. 88; Archaeological Society at Athens to E. Capps, 25 July 1927, n. 102; E. Capps to D. Papoulias, President of the Archaeological Society at Athens, 26 July 1927, where it is mentioned that the ASCSA was to obligate itself to appoint to the Agora staff one member of the Archaeological Society for every five American archaeologists.

89. ASCSA, Administrative Records, R. Carpenter to the Representatives of the residents of the area of the Agora, 12 November 1927.

90. ASCSA, Administrative Records, A. Adossidis to E. Capps, 2 March 1931.

91. Papageorgiou-Venetas 1994, 248-68.

92. Cf. Liakos 2007, Ch. 7.

Prehistory in institutional practice: a view from one of its North American Centers, in: Cherry J.F. et al. (eds), Prehistorians Round the Pond: Reflections on Aegean Prehistory as a Discipline (Ann Arbor) 94-113.

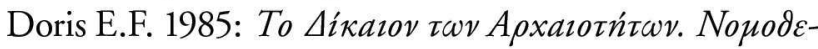

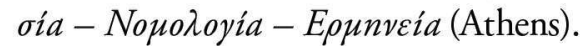

Dyson S.L. 1998: Ancient Marbles to American Shores: Classical Archaeology in the United States (Philadelphia).

Dyson S.L. 2002: The Archaeological Institute of America between the Wars, in: Allen S.H. (ed.), Excavating our Past: Perspectives on the History of the Archaeological Institute of America (Boston) 157-68. 
Dyson S.L. 2006: In Pursuit of Ancient Pasts: a History of Classical Archaeology in the Nineteenth and Twentieth Centuries (Yale).

Hamilakis Y. \& Yalouri E. 1996: Antiquities as symbolic capital in modern Greek society, Antiquity 70, 117-29.

Hamilakis Y. 1999: Stories from exile: fragments from the cultural biography of the Parthenon (or 'Elgin') marbles, World Archaeology 31, 303-20.

Herzfeld M. 1982: Ours Once More: Folklore, Ideology, and the Making of Modern Greece (Austin).

Herzfeld M. 1991: A Place in History: Social and Monumental Time in a Cretan Town (Princeton).

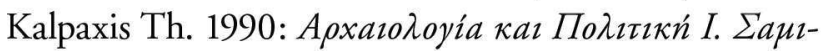

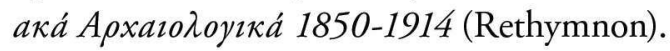

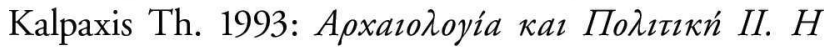

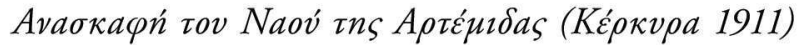
(Rethymnon).

Karadimou-Yerolympou A. \& Papamichos N. 1992: Pú日-

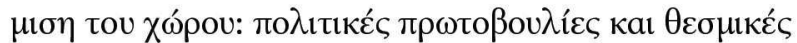

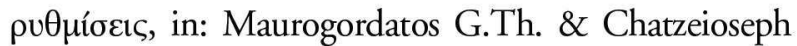

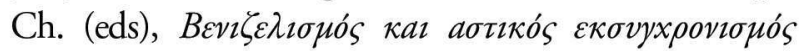
(Herakleion) 113-32.

Kotsakis K. 1991: The powerful past: theoretical trends in Greek archaeology, in: Hodder I. (ed.), Archaeological Theory in Europe: the Last Three Decades (London) 65-90.

Kotsakis K. 1998: The Past is Ours: images of Greek Macedonia, in: Meskell L. (ed.), Archaeology under Fire: Nationalism, Politics and Heritage in the Eastern Mediterranean and Middle East (London and New York) 44-67.

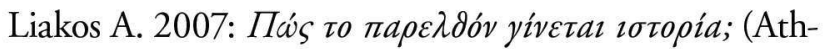
ens).

Lord L.E. 1947: A History of the American School of
Classical Studies at Athens 1882-1942 (Cambridge, $\mathrm{MA})$.

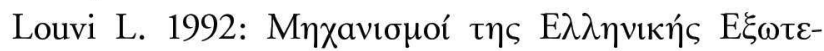

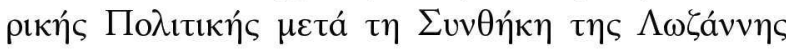
(1923-1928), in: Maurogordatos G.Th. \& Chatzei-

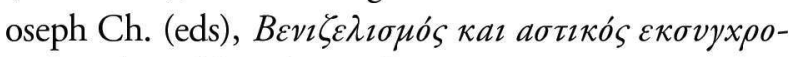
viouós (Herakleion) 391-403.

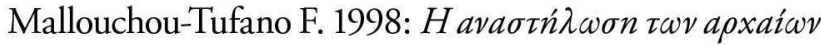

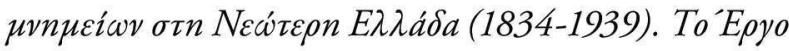

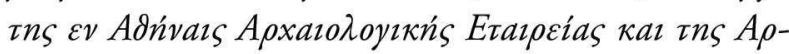

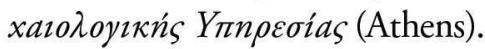

Mallouchou-Tufano F. 2001: From the 19th to the 21st Century: metamorphoses of the archaeological landscape in Athens, in: Staikos K.S. (ed.), Athens: from the Classical Period to the Present Day (5th century B.C. - A.D. 2000) (Athens) 308-43.

Morris I. 1994: Archaeologies of Greece, in: Morris I. (ed.), Classical Greece: Ancient Histories and Modern Archaeologies (Cambridge) 8-47.

Papageorgiou-Venetas A. 1994: Athens: the Ancient Heritage and the Historic Cityscape in a Modern Metropolis (Athens).

Philadelpheus A. 1994: Mvnucía Adnváv (10th revised edition; Athens).

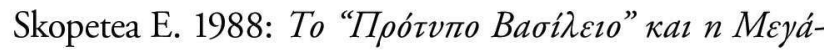

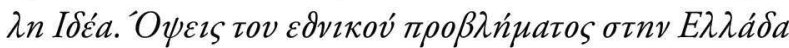
(1830-1880) (Athens).

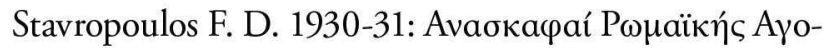

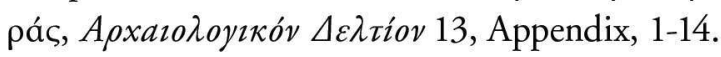

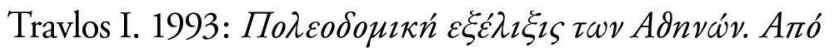

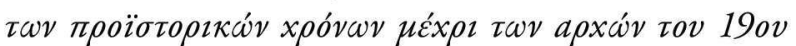
arćvos (2nd edition; Athens).

Yalouri E. 2001: The Acropolis: Global Fame, Local Claim (Oxford). 